\title{
Knowledge, attitude and practice of organ donation in urban areas of Puducherry - A Community based study
}

\author{
Devi K. ${ }^{1 *}$, Leondra L. ${ }^{2}$, Poovitha R. $^{3}$ \\ DOI: https://doi.org/10.17511/ijphr.2018.i2.06 \\ 1* Devi K., Associate Professor, Department of Community Medicine, Indira Gandhi Medical College and Research Institute, Kathirkamam, \\ Puducherry, India. \\ 2 Lydia Leondra, IInd year Medical Student, Indira Gandhi Medical College and Research Institute, Kathirkamam, Puducherry, India. \\ 3 Poovitha R., Statistician, Indira Gandhi Medical College and Research Institute, Kathirkamam, Puducherry, India.
}

Objectives: To determine the knowledge, attitudes and practices regarding organ donation in a selected adult urban population in Pondicherry. Methods: Simple random sampling was used to generate a sample of 100 in urban service areas of IGMC \& RI. Face to face interview was conducted based on a pre-tested questionnaire in selected urban areas of Pondicherry. Data was analysed using SPSS v. 22 and associations were tested using the Pearson's Chi square test. Results: $57 \%$ of the participants in this survey had adequate knowledge score for Organ Donation. Knowledge about organ donation was significantly associated with gender, religion, education and income. Television emerged as the major source of information. Only $2 \%$ had donated an organ. Both were volunteers who have donated blood. Conclusions: Better knowledge may ultimately translate into the act of donation. Effective measures should be taken to educate people with relevant information with the involvement of media and doctors.

Keywords: Organ donation, Knowledge, Attitude, Practice, Urban, Pondicherry

\section{Corresponding Author}

Devi K., Associate Professor, Department of Community Medicine, Indira Gandhi Medical College and Research Institute, Kathirkamam, Puducherry, India.

Email: devi.kittu@rediffmail.com
How to Cite this Article

To Browse

Devi K, Leondra L, Poovitha R. Knowledge, attitude and practice of organ donation in urban areas of Puducherry - A Community based study. Public Health Rev Int J Public Health Res. 2018;5(2):82-91. Available From

https://publichealth.medresearch.in/index.php/ijphr/ article/view/87

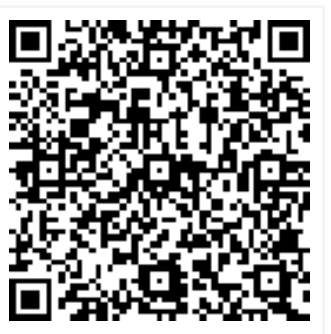

Manuscript Received 2018-06-09

Conflict of Interest No

Review Round 1
2018-06-18
Funding
Nil

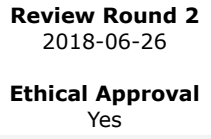

Review Round 3

Accepted 2018-06-30

(c) 2018 by Devi K., Lydia Leondra, Poovitha R. and Published by Siddharth Health Research and Social Welfare Society. This is an Open Access article licensed under a Creative Commons Attribution 4.0 International License https://creativecommons.org/licenses/by/4.0/ unported [CC BY 4.0]. 


\section{Introduction}

Organ transplantation is recognized as one of the most gripping medical advances of the century as it provides a way of giving the gift of life to patients who need them. The issue of organ donation is complex and multi-factorial involving medical, legal, ethical, organizational, and social factors [1-4].

Organ trans-plantation saves thousands of lives worldwide. According to WHO, globally 6600 kidney donations, 21000 liver donations and 6000 heart donations was transplanted [5].

Organ shortages are a global problem, but Asia lags behind much of the rest of the world. Organ donation following brain stem death is infrequent in India. The current organ donation for cadaver in India is 0.08 per million while Spain tops the list with 35 per million [6].

There is a huge shortage of organs in India, and patients die while on the waiting list as they do not get an organ on time. The increasing incidence of organ failure and inadequate supply has created a wide gap which has resulted in increasing number of deaths while waiting.

Only $5 \%$ of all patients with end-stage kidney disease are successful in undergoing kidney transplantation [7]. The current demand in the country for kidney transplants is 150,000 ; liver 200,000 and heart 150,000 [8].

Human organ donation was legalized in India since 1994 through 'The transplantation of Human Organs Act, 1994' [9]. India has a fairly well-developed corneal donation programme however donation after brain death is slow.

To promote organ donation after brain death the government enacted "The Transplantation of Human Organs Act" amendment in 2011 [10].

Every year, close to six lakh people die due to organ failure. Conversely, with 70 per cent of India's 1.4 lakh accident victims diagnosed as brain dead annually, the country has 80,000 potential organ donors.

Yet, organs from only about 120 are retrieved, making the percentage of cadaver donations a dismal 0.08 per million of the population, according to MOHAN Foundation.

On the other hand, in most developed countries, the cadaveric conversion is approximately $25 \%$ to $30 \%$.
This result in $90 \%$ of all organs for transplants coming from brain-dead donors [11].

The greatest obstacle to organ donation is the refusal of family consent [12]. Organ donation rates could be increased by enhancing the quality of hospital care and ensuring that the request for donation is handled in a way that meets the families informational and emotional needs [13].

Lack of awareness along with myths and misconceptions add to the low percentage of organ donation. Knowledge, attitudes, and behaviours are essential factors in fostering an environment that positively influences organ donation rates [14-16]. Globally the prevalence of knowledge of organ donation ranges from 60 to $85 \%$, which varies between countries [17].

Most of the research evidence on organ donation is from developed countries. There is dearth of information in India. The aim of our study is to fill these gaps regarding awareness of organ donation among general public.

\section{Objectives}

01. To determine the knowledge, attitudes and practices regarding organ donation among adults population in urban areas of Puducherry.

02. To find the predictors of knowledge of organ donation in urban area of Pondicherry.

\section{Methods}

01. Type of study: Community based Crosssectional study

\section{2. a) Inclusion criteria:}

- All the young adults between the age group of $18-40$ years.

- Participants belonging to urban service areas of IGMC \& RI.

- Participants agreeing to participate and providing

\section{3. b) Exclusion criteria:}

- Indiviguals less than 18 years and more than $\mathbf{4 0}$

- Indiviguals not belonging to the service areas of IGMC \& RI.

- Participants not willing to participate in the study/ to give consent.

Study Duration: The study was conducted from March 2015 - July 2015. 
Study Area: The study was conducted among young adult population in the age group of $18-40$ years in Lawspet and Karikalampakkam which is urban area of Indira Gandhi Medical College and Research Institute (IGMC \& RI).

Study Population: All the participants in the age bracket of 18 - 40 years belonging to the urban service areas of Indira Gandhi Medical College and Research Institute (IGMC \& RI) was included in the study. Further simple random sampling was used to draw the samples in urban service areas.

Sample size: A sample size of 99 was calculated assuming a prevalence of 52.8 from a previous study for knowledge, attitudes and practices of organ donation, at $95 \%$ confidence interval and a sample error of $10 \%$ [18].

The formula used for calculation was $\mathbf{N}=\mathbf{Z}$ $\mathbf{a} / \mathbf{2 2} * \mathbf{p} * \mathbf{q} /(\mathbf{d}) \mathbf{2}$. This was rounded of to 100 . A total sample of 100 adult subjects was covered.

Vii. Technique and Tools: Allthe participant chosen was interviewed individually by using a pretested, structured questionnaire.

The Dean of the college was contacted and the purpose of the study was explained to him in detail. Permission was obtained from "Institute Research Committee" and "Institution Ethical Committee" before the start of study.

Initially, the questionnaire was pretested among 10 community members from another village. Pretesting was done among adults in the same age brackets, in a similar setting in another urban area to screen for potential problems in the questionnaire after which the questionnaire was finalized.

The purpose of the study and the contents of the form was explained in detail to each participants selected. The detailed consent form was given individually to all the participants in the study. One to one interview was conducted by the investigator using a pretested, structured questionnaire.

In case the selected participants are not available at the time of the first visit, two more visits were made to contact them personally. If after these 3 visits contact could not be established, no further attempt was made to contact them.

Questionnaire: The questionnaire comprises of identification data, socio-demographic information and knowledge, attitude and practice regarding organ donation in the community.
Knowledge, Attitude and Practice Variables: Knowledge of the respondents was assessed through questions regarding meanings of the terms "organ donation", awareness of donation by living people as well as cadavers, purpose, organs which can be donated and the sources of information for their knowledge.

Attitudes of the respondents regarding organ donation was determined through questions regarding opinions on issues such as the willingness to donate organs in the future, influence of religion on attitude towards organ donation, allowance for incentive-based organ donation and factors influencing choice of recipient for future donation. Practices were measured by enquiring about actual donation of any organ, reason for donation and whether they have signed an organ donation card.

Methods of statistical analysis to be used:Data was analyzed using SPSS version - 22. Descriptive statistics, frequency, mean and standard deviation was estimated as appropriate. Chi -square test was be used to find the association between the attributes.

Ethical Considerations: The study was given ethical approval by Institute Ethics Committee and Institute Research Council. All ethical requirements including confidentiality of responses and informed consent were maintained throughout the project.

\section{Results}

A total of 100 individuals were approached for participation in our survey. Table 1 provides details of the socio-demographic characteristics of respondent population. Among the population studied $59 \%$ of them were in the age group of 31 40 years. The proportion of male $(60 \%)$ and females $(40 \%)$ were represented in the study.

$56 \%$ of the participants had completed middle school education. Among the study participants $44 \%$ of them belonged to income group of 5000 10,000 . $45 \%$ were unemployed and $94 \%$ of the study participants were Hindu by religion.

Table-1: Socio Demographic characteristics of Study Population.

Socio demographic Variables Subcategory Frequency $(\mathrm{n}=100) \%$

\begin{tabular}{|l|l|l|l|}
\hline \multirow{3}{*}{ Age Group } & $18-30$ years & 41 & 41 \\
\cline { 2 - 4 } & $31-40$ years & 59 & 59 \\
\hline \multirow{3}{*}{ ender } & Males & 60 & 60 \\
\cline { 2 - 4 } & Females & 40 & 40 \\
\hline
\end{tabular}


Devi K. et al: Knowledge, attitude and practice of organ

\begin{tabular}{|l|l|l|l|}
\hline \multirow{5}{*}{ Education } & Illiterate & 2 & 2 \\
\cline { 2 - 5 } & Primary School & 14 & 14 \\
\cline { 2 - 5 } & Middle School & 56 & 56 \\
\cline { 2 - 5 } & High School & 25 & 25 \\
\cline { 2 - 5 } & Diploma & 3 & 3 \\
\cline { 2 - 5 } & Graduate & 0 & 0 \\
\hline \multirow{5}{*}{ Income } & $<5000$ & 20 & 20 \\
\cline { 2 - 5 } & $>$ Rs. 5, 000 - 10,000 & 44 & 44 \\
\cline { 2 - 5 } & $>10,000-20,000$ & 29 & 29 \\
\cline { 2 - 5 } & $>20,000-50,000$ & 7 & 7 \\
\hline \multirow{5}{*}{ Religion } & Unemployed & 45 & 45 \\
\cline { 2 - 5 } & Unskilled & 16 & 16 \\
\cline { 2 - 5 } & Semiskilled & 27 & 27 \\
\cline { 2 - 5 } & Skilled & 11 & 11 \\
\cline { 2 - 4 } & Clerical, shop owner & 94 & 94 \\
\hline & Hindu & & 1 \\
\hline
\end{tabular}

\begin{tabular}{|l|l|l|l|}
\hline \multirow{2}{*}{} & Christian & 3 & 3 \\
\cline { 2 - 4 } & Muslim & 3 & 3 \\
\hline
\end{tabular}

Participants who hadn't heard of the term "Organ Donation" were not asked to answer other questions of the Organ Donation section. They were included among respondents who were not adequately knowledgeable about organ donation.

These cumulative scores were based on a set of 10 questions; people achieving $\geq 50 \%$ score were regarded as being adequately knowledgeable while those achieving less than $50 \%$ scores were regarded as being inadequately knowledgeable. Accordingly, $57 \%$ of the respondents in this survey had adequate knowledge score for organ donation while $43 \%$ had inadequate knowledge.

Table-2: Knowledge Score of Organ Donation By Socio-demographic Variables.

\begin{tabular}{|c|c|c|c|c|c|c|}
\hline \multirow[t]{3}{*}{ Socio-demographic Variables } & \multirow[t]{3}{*}{ Sub category } & \multicolumn{4}{|c|}{ Knowledge Status of Organ Donation } & \multirow[t]{3}{*}{ p-value } \\
\hline & & \multicolumn{2}{|c|}{ Adequate knowledge Score } & \multicolumn{2}{|c|}{ Inadequate knowledge score } & \\
\hline & & Frequency $(n=57)$ & $\%$ & Frequency $(n=43)$ & $\%$ & \\
\hline \multirow[t]{2}{*}{ Age (years) } & $18-30$ & 21 & 36.8 & 20 & 46.5 & \multirow[t]{2}{*}{$p=0.412$} \\
\hline & $31-40$ & 36 & 63.2 & 23 & 53.5 & \\
\hline \multirow[t]{2}{*}{ Gender } & Male & 28 & 49.1 & 32 & 74.4 & \multirow[t]{2}{*}{$p=0.014 *$} \\
\hline & Female & 29 & 50.9 & 11 & 25.6 & \\
\hline \multirow[t]{5}{*}{ Education } & Illiterate & 0 & 0 & 2 & 4.6 & \multirow[t]{5}{*}{$p=0.009 *$} \\
\hline & Primary School & 5 & 8.8 & 9 & 20.9 & \\
\hline & Middle School & 30 & 52.6 & 26 & 60.4 & \\
\hline & High School & 21 & 36.8 & 4 & 9.3 & \\
\hline & Diploma & 1 & 1.8 & 2 & 4.7 & \\
\hline \multirow[t]{5}{*}{ Occupation } & Unemployed & 23 & 40.4 & 22 & 51.2 & \multirow[t]{5}{*}{$p=0.505$} \\
\hline & Unskilled & 10 & 17.5 & 6 & 13.9 & \\
\hline & Semiskilled & 16 & 28.1 & 11 & 25.6 & \\
\hline & Skilled & 8 & 14 & 3 & 7 & \\
\hline & Semi professional & 0 & 0 & 1 & 2.3 & \\
\hline \multirow[t]{3}{*}{ Religion } & Hindu & 57 & 100 & 37 & 86 & \multirow[t]{3}{*}{$p=0.015^{*}$} \\
\hline & Christian & 0 & 0 & 3 & 7 & \\
\hline & Muslim & 0 & 0 & 3 & 7 & \\
\hline \multirow[t]{4}{*}{ Income } & $<5000$ & 4 & 7 & 16 & 37.2 & \multirow[t]{4}{*}{$p=0.000 *$} \\
\hline & $>5000-10,000$ & 22 & 38.6 & 22 & 51.2 & \\
\hline & $>10,000-20,000$ & 25 & 43.9 & 4 & 9.3 & \\
\hline & $>20,000-50,000$ & 6 & 10.5 & 1 & 2.3 & \\
\hline
\end{tabular}

$* \mathrm{P}$ value $<0.05$ is considered as significant

Table 2 shows the proportion of respondents with adequate and inadequate knowledge in relation to different socio-demographic variables. For knowledge status of respondents, the following
Variables were subjected to chi square analysis : Gender $(p=0.014)$, education $(p=0.009)$, religion $(p=0.015)$ and income $(p=0.000)$ was found to have a significant association with knowledge scores of organ donation. 
Table-3.1: Attitude regarding Organ Donation among respondents:

\begin{tabular}{|c|c|c|c|}
\hline Attitudinal variables & Responses & Frequency & $\%$ \\
\hline \multirow[t]{3}{*}{ Effective $(n=100)$} & Yes & 93 & 93 \\
\hline & No & 1 & 1 \\
\hline & Don't' know & 6 & 6 \\
\hline \multirow[t]{4}{*}{ Attitude $(n=94)$} & Never consider donating an organ & 5 & 5.3 \\
\hline & Think About it & 30 & 31.9 \\
\hline & Donate under special circumstances & 47 & 50 \\
\hline & Definitely want to donate irrespective of circumstances & 12 & 12.8 \\
\hline \multirow[t]{7}{*}{ Special Circumstances $(n=47)$} & Accident & 8 & 17.0 \\
\hline & After death & 29 & 61.7 \\
\hline & Depending on need & 1 & 2.1 \\
\hline & For relatives & 3 & 6.4 \\
\hline & If close relatives are in need & 2 & 4.3 \\
\hline & If needed & 1 & 2.1 \\
\hline & Necessity & 3 & 6.4 \\
\hline \multirow[t]{7}{*}{ Greatest Importance $(n=94)$} & Relation to the person & 15 & 16 \\
\hline & Age of recipient & 9 & 9.6 \\
\hline & Religion of recipient & 4 & 4.2 \\
\hline & Health status of recipient & 22 & 23.4 \\
\hline & Substance abuse of body & 3 & 3.2 \\
\hline & Assurance of respectful treatment of organ & 3 & 3.2 \\
\hline & None of the above & 38 & 40.4 \\
\hline \multirow[t]{2}{*}{ Promoted $(n=94)$} & Yes & 78 & 93.6 \\
\hline & No & 16 & 6.4 \\
\hline \multirow[t]{4}{*}{ Reasons for not promoting $(n=16)$} & Fear that organs could be wasted & 5 & 31.3 \\
\hline & Would not want to be mutilated & 4 & 25 \\
\hline & Family parents refusal & 4 & 25 \\
\hline & Can lead to organ trade/ violation of rights & 3 & 18.7 \\
\hline \multirow[t]{3}{*}{ Any risks $(n=94)$} & Yes & 21 & 22.4 \\
\hline & No & 63 & 67 \\
\hline & Don't know & 10 & 10.6 \\
\hline \multirow[t]{3}{*}{ What are the risk $(n=21)$} & Infection & 16 & 76.2 \\
\hline & Bodily Weakness & 4 & 19 \\
\hline & Pain & 1 & 4.8 \\
\hline \multirow[t]{3}{*}{ Cost $(n=94)$} & Yes & 13 & 13.8 \\
\hline & No & 67 & 71.3 \\
\hline & Don't know & 14 & 14.9 \\
\hline \multirow[t]{4}{*}{ Sign donor card $(n=94)$} & Yes & 60 & 63.8 \\
\hline & No & 16 & 17 \\
\hline & Not Sure & 6 & 6.4 \\
\hline & Need more information & 12 & 12.8 \\
\hline \multirow[t]{4}{*}{ How effective $(n=94)$} & Very Effective & 10 & 10.6 \\
\hline & Effective rest of time & 24 & 25.5 \\
\hline & Partially effective & 25 & 26.7 \\
\hline & Not very effective & 35 & 37.2 \\
\hline \multirow[t]{4}{*}{ Afraid of misuse $(n=94)$} & Never & 45 & 47.9 \\
\hline & Sometimes & 14 & 14.9 \\
\hline & Most of the time & 9 & 9.5 \\
\hline & All the times & 26 & 27.7 \\
\hline
\end{tabular}


Table-3.2: Attitude regarding Organ Donation among respondents:

\begin{tabular}{|c|c|c|c|}
\hline \multirow[t]{3}{*}{ Need for law $(n=94)$} & Yes & 74 & 78.7 \\
\hline & No & 17 & 18.1 \\
\hline & Don't Know & 3 & 3.2 \\
\hline \multirow[t]{3}{*}{ Ethical Issues $(n=94)$} & Very Important & 39 & 41.5 \\
\hline & Important to some degree & 23 & 24.5 \\
\hline & Not important & 32 & 34.0 \\
\hline \multirow[t]{3}{*}{ Does Religion allows $(n=94)$} & Yes & 61 & 64.9 \\
\hline & No & 11 & 11.7 \\
\hline & Don't know & 22 & 23.4 \\
\hline \multirow[t]{5}{*}{ Relations $(n=61)$} & Family Members & 6 & 9.8 \\
\hline & Friends & 3 & 4.9 \\
\hline & Colleagues & 2 & 3.3 \\
\hline & Anyone & 48 & 78.7 \\
\hline & Others & 2 & 3.3 \\
\hline \multirow[t]{3}{*}{ Smoker $(n=61)$} & Smoker & 1 & 1.6 \\
\hline & Non Smoker & 53 & 86.9 \\
\hline & Don't know & 7 & 11.5 \\
\hline \multirow[t]{3}{*}{ Drinker $(n=61)$} & Drinker & 0 & 0 \\
\hline & Non Drinker & 55 & 90.2 \\
\hline & Don't know & 6 & 9.8 \\
\hline \multirow[t]{4}{*}{ Age $(n=61)$} & Young person $\leq 30 \mathrm{yrs}$ & 40 & 65.6 \\
\hline & Middle aged $30-50$ yrs & 15 & 24.6 \\
\hline & Elderly persons > 50 yrs & 4 & 6.6 \\
\hline & Don't Know & 2 & 3.2 \\
\hline \multirow[t]{3}{*}{ Mentally retarded $(n=61)$} & entally retarded & 19 & 31.1 \\
\hline & Mentally Sound & 38 & 62.3 \\
\hline & Don't Know & 4 & 6.6 \\
\hline \multirow[t]{3}{*}{ Physically disabled $(n=61)$} & Physically Disabled & 22 & 36.1 \\
\hline & Physically sound & 35 & 57.3 \\
\hline & Don't Know & 4 & 6.6 \\
\hline \multirow[t]{3}{*}{ Religion $(n=61)$} & Person belonging to some religion & 8 & 13.1 \\
\hline & Person belonging to differentreligion & 43 & 70.5 \\
\hline & Don't Know & 10 & 16.4 \\
\hline
\end{tabular}

The attitude among our study population towards various aspects of organ donation is shown in Table 3.1 and 3.2. Majority (93\%) opined that organ donation is effective. One half of the respondents said that they would like to donate under special circumstances. The most important special circumstance was after death (61.7\%). $23.4 \%$ of the participants said that they would give importance to age of recipients. Majority $(93.6 \%)$ of them said that organ donation can be promoted. Of the 16 people who felt that organ donation should not be promoted, almost an equal proportion said that fear of organs being wasted $(31.3 \%)$ and fear of mutilation ( $25 \%)$ and family refusal $(25 \%)$.
Another $18.7 \%$ of them said that this might lead to organ trade. One-fifth $(22.4 \%)$ opined that risk is involved in organ donation which includes infection $(76.2 \%)$ and body weakness (19\%). Majority, $71.3 \%$ of therespondents opined that cost of organ transplant need not be criteria for prescription. More than half $(63.8 \%)$ of the participants were in favour of signing the donar card. Only $17 \%$ of them refused to sign the donor card. $30 \%$ of them were afraid of misuse all the time. $78.7 \%$ of them said that law should be enforced to avoid misuse. $41.5 \%$ said that ethical issues were important in organ donation. For majority (64.9\%) religion was not a hindrance for organ donation. 
$48(78.7 \%)$ opined that organ donation can be done to anyone irrespective of blood relation. Majority of the participants said that they would like to donate their organs to non-smoker $(86.9 \%)$ andnonalcoholic $(90 \%)$ respectively. $62.3 \%$ preferred donating their organs to mentally sound person. Similarly $57.3 \%$ of them preferred their organs to be donated to physically sound persons. Only $36 \%$ of them said that they would prefer physically disabled person for donation. Majority (70.5) said that organ donation can be done for people belonging to different religion.

\section{Table-4: Practice of organ donation among} urban subjects:

\begin{tabular}{|l|l|l|l|}
\hline \multicolumn{1}{|c|}{ Practice } & \multicolumn{1}{|c|}{ Sub category } & \multicolumn{1}{|c|}{ Frequency $(\mathbf{n}=94)$} & \multicolumn{1}{c|}{$\%$} \\
\hline \multirow{5}{*}{ Know Anyone } & Family Member & 12 & 12.8 \\
\cline { 2 - 4 } & Friend & 16 & 17 \\
\cline { 2 - 4 } & No One & 65 & 69.1 \\
\cline { 2 - 4 } & Others & 1 & 1.1 \\
\hline \multirow{3}{*}{ Have you donated } & Yes & 2 & 2.1 \\
\cline { 2 - 4 } & No & 92 & 97.9 \\
\hline \multirow{3}{*}{ Reason } & Blood & 2 & 2.1 \\
\cline { 2 - 4 } & NA & 92 & 97.9 \\
\hline \multirow{3}{*}{ Have You Signed } & Volunteer & 2 & 2.1 \\
\cline { 2 - 4 } & NA & 92 & 97.9 \\
\hline \multirow{3}{*}{ Family Allow } & Yes & 1 & 1.1 \\
\cline { 2 - 4 } & No & 93 & 98.9 \\
\cline { 2 - 4 } & Likely & 33 & 35.1 \\
\cline { 2 - 4 } & Possible & 11 & 11.7 \\
\cline { 2 - 4 } & Unlikely & 16 & 17 \\
\cline { 2 - 4 } & Never & 8 & 27.7 \\
\cline { 2 - 4 } & Don't Know & 26 & \\
\hline
\end{tabular}

Table-5: Sources of information of organ donation.

\begin{tabular}{|l|l|l|}
\hline Sources of Information & Frequency $(\mathbf{n}=\mathbf{1 5 1}) *$ & Percentage \\
\hline Heard from a doctor & 9 & 6 \\
\hline Internet & 10 & 6.6 \\
\hline TV & 70 & 46.4 \\
\hline Radio & 16 & 10.6 \\
\hline Newspapers & 39 & 25.8 \\
\hline Friends/Colleagues & 5 & 3.3 \\
\hline Others & 2 & 1.3 \\
\hline
\end{tabular}

* Multiple responses

Table 4 shows the practice of organ donation among urban subjects. Majority (69.1\%) do not know anyone who had donated any organ. Only 2 of the respondents had donated organ during their life time. Both of them had donated blood and were volunteers. Majority (98.9\%) had not signed the donar card.
Nearly half (35.1\%) of the participants family allows organ donation. Source of information regarding organ donation is given in Table 5. Television (46.4\%) was the leading source of information for most people regarding organ donation. Only a minority (6\%) of the respondents reported doctors as being their source of information.

\section{Discussion}

We aimed to study the knowledge, attitudes and practices regarding organ donation in a selected adult population of urban Pondicherry. Our analysis of the collected data revealed interesting findings. Our study showed a slightly lower prevalence of adequate knowledge (57\%) regarding organ donation when compared to $88 \%$ have heard about organ donation in another study [19]. Similarly a study done in Pakistan, 65.5\% reported adequate knowledge [17]. A study done in Lagos, Nigeria also reported that $60 \%$ respondents were aware of organ donation [20]. This difference can be explained on the basis of two reasons. Firstly, this could be because of the difference in the study population; ours being the community study while the previous survey was done among patients. Secondly, different knowledge variables have been used in our study as compared to the previous study for the assessment of knowledge status of respondents with regards to organ donation. We also observed that the awareness was not uniform across the study population.

Gender, Religion, education and income was significantly associated with knowledge levels. In another study awareness was highest among those belonging to higher socioeconomic status and lowest among the uneducated and unemployed [19]. These findings are in contrast to a study in Ernakulam where income and occupation had no influence on the level of awareness [21]. In contrast to the previous Pakistani study which showed a significant association of the willingness to donate with gender [17]. A study from Nigeria showed that the willingness to donate an organ was significantly associated with younger age, but not with gender [20]. Another important finding was that only $9 \%$ of them were willing to sign a donar card, in contrast to findings from other studies $[19,22]$. Our study findings are different from data from other developing countries like Nigeria where only $30 \%$ of the respondents expressed a willingness to donate in one survey [20]. In a study from Ohio, over $96 \%$ of respondents expressed favourable attitudes toward donation[23]. 
Our study also shows that religious beliefs of the people did not hinder their decision to donate organs which was similar to the findings from other studies $[19,24,25]$. In this study, only $35 \%$ of them said that their family are likely to allow organ donation. The objection by family members was the most common reason that prevents them from donating organs [19]. This underlines the importance of involving family members in decisionmaking regarding organ donation. In our study, $78.7 \%$ of individuals were willing to donate an organ to anyone.

Comparing findings from other studies, where $51 \%$ respondents mentioned that they would like to donate their organs to family members [22]. These percentages are comparable to data obtained in studies from neighbouring countries like China were $49.8 \%$ respondents indicated they are willing to be living organ donors. Sixty two percent individuals designated relatives as their most probable recipients [26].

A study from Qatar reported that the majority of subjects preferred donating organs to their close relatives and friends [27]. In our study majority $(93.6 \%)$ of them were in favour of the promotion of organ donation. This is lower compared to other studies $57 \%$ and $87 \%$ were in favor of organ donation and its promotion in the future[22,28]. We can explain this difference on the basis of the reservation some people might have in view of the recent mushrooming growth of organ trade and trafficking in the country.

The negativity projected by the image of organ trade can have a detrimental effect even on the organ donation for altruistic purposes because it weakens the confidence of the people in the transparency and authenticity of the process. In our study $78.7 \%$ of the people expressed the need for effective legislation to govern organ donation practices. This awareness about the legal provisions of organ donation will prevent them from getting exploited by the illegal organ trade.

Effective legislation is indeed important to regulate the future practices related to organ transplantation in the country; the lack of which has allowed organ trade to spawn in recent years However, $22.4 \%$ of the respondents said that risks are involved if they donate their organs. Among the risks majority of them reported infections and body weakness. Media was the major source of information about organ donation, similar to the earlier studies $[19,24,29]$.
It is a disappointing trend to note that only $6 \%$ people had heard about organ donation, through a doctor. Comparing our results with the previous study done in Pakistan, it is clear that television, print media and doctors fall in the same order of frequency with regards to being sources of information for organ donation[17].

Efforts to judiciously increase the participation of doctors in the process should start at the root level. As a first step, the medical curriculum should increase medical students' awareness of the organ shortage problem and how it can be effectively addressed [30].

At the end of the survey, information regarding the procedure for organ donation was provided to all the participants. Those participants who were willing to donate organs were guided to the nearest health facility. The strength of the study is that this is a community-based study and one of the few studies in India that have assessed the awareness and attitudes regarding organ donation among the people in urban community.

\section{Limitations}

We have used a quantitative tool to assess knowledge, attitudes and practices in our survey. This approach may pose some methodological problems in the procurement of all necessary information for this study. Nevertheless, this study forms an important baseline document for future studies and a qualitative tool can be employed in further studies to gauge in-depth information.

\section{Conclusion}

Measures should be taken to educate people with relevant information, including the benefits of organ donation and possible risks as well so that people can make informed choices in the future. The result of this research indicates that there is need for more intensified interdisciplinary discussion and information to prepare the general population about organ donation.

Television, newspapers and doctors can be used as efficient sources of information. The communication gap between patients and doctors should be bridged for the generation of a more favourable attitude towards organ donation in the population. This needs to be addressed through awareness campaigns in the community and also popularized during their contact with the health system. 


\section{Acknowledgements}

I express my heart-felt gratitude to Institute Research Committee, Institute Ethical Committee for having approved this study. I profusely acknowledge Deputy Director of Public health (DDPH) for having given permission to conduct this study in the service areas of IGMC\&RI. Last but not the least I would like to thank the all the respondents who participated in this study without which this study would not have been possible.

\section{Contribution of authors}

Dr Devi K. was involved in designing the study, review process and manuscript writing. Ms. Lydia Leondrawas involved in data collection, data entry and helping in review process. R. Poovithahad contributed in data cleaning and data analysis process.

\section{Impact of current study}

Most of the research evidence on organ donation is from developed countries. There is dearth of information in India. The current study has filled these gaps regarding awareness of organ donation among general public. The result of this research indicates that there is need for more intensified interdisciplinary discussion and information to prepare the general population about organ donation.

\section{Reference}

01. Edwards TM, Essman C, Thornton JD. Assessing racial and ethnic differences in medical student knowledge, attitudes and behaviors regarding organ donation. J Natl Med Assoc. 2007 Feb;99(2)131-7.

[Crossref]

02. Ghods AJ. Ethical issues and living unrelated donor kidney transplantation. Iran J Kidney Dis. 2009 Oct;3(4)183-91.

[Crossref]

03. Edwards AG, Newman A, Morgan JD. Exposure to the field of renal transplantation during undergraduate medical education in the UK. BMC Med Educ. 2005;Sep-14;5;32.

[Crossref]
04. Edwards AG, Weale AR, Morgan JD. A survey of medical students to assess their exposure to and knowledge of renal transplantation. BMC Medical Education. 23 Dec;2004.

DOI: $10.1186 / 1472-6920-4-32$ [Crossref]

05. Shimazono Y. The state of the international organ trade. Bulletin of the World Health Organization. 2007;85;901-80.

[Crossref]

06. Campaign for an effective organ donor system. Available on: [Article] [Crossref]

07. Sakhuja V, Sud K. End-stage renal disease in India and Pakistan- burden of disease and management issues. Kidney Int Suppl. 2003 Feb;63(S83)115-8.

DOI: $10.1046 / j .1523-1755.63 .583 .24 . x \quad$ [Crossref]

08. International organ donation registry- Organs, Tissues \& Cells. 2010;13;5-8.

[Crossref]

09. The Transplantation of Human Organs Act, 1994. New Delhi- Legislative Department- 1994. Ministry of Law, Justice and Company Affairs.

Available at: [Article] [Crossref]

10. Illegal organ transplantation can attract 10 years jail. The Hindu. 13 August 2011.

[Article] [Crossref]

11. MOHAN (Multi Organ Harvesting Aid Network). Available at: [Article] [Crossref]

12. Gortmaker $\mathrm{SL}$, Beasley $\mathrm{CL}$, Sheehy $\mathrm{E}$, Lucas $\mathrm{BA}$, Brigham LE, Grenvik $A$ et al. Improving the request process to increase family consent for organ donation. J Transpl Coord. 1998 Dec;8(4);210-17.

[Crossref]

13. DeJong W, Franz HG, Wolfe SM, et al. Requesting organ donation- an interview study of donor and nondonor families. Am J Crit Care. 1998 Jan;7(1)13-23.

[Crossref]

14. Rithalia A, McDaid C, Suekarran S, et al. A systematic review of presumed consent systems for deceased organ donation. Southampton (UK)- NIHR Journals Library. 2003.

DOI: $10.3310 /$ hta13260 [Crossref] 
15. Rithalia A, Mc Daid C, Suekarran S, et al. Impact of presumed consent for organ donation on donation rates- a systematic review. BMJ. 2009 Jan 14;338;a3162.

doi: $10.1136 /$ bmj.a3162 [Crossref]

16. Mekahli D, Liutkus A, Fargue S, et al. Survey of first-year medical students to assess their knowledge and attitudes toward organ transplantation and donation. Transplant Proc. 2009 Mar;41(2)634-8.

doi: $10.1016 /$ j.transproceed.2008.12.011 [Crossref]

17. Ashraf O, Ali S, Ali SA, et al. Attitude toward organ donation: a survey in Pakistan. Artif Organs. 2005 Nov;29(11)899-905.

DOI: $10.1111 / j .1525-1594.2005 .00153 . x$ [Crossref]

18. Vijayalakshmi $P$, Sunitha TS, Gandhi $S$, Thimmaiah R, Math SB. Knowledge, Attitude and behaviour of the general population towards organ donation- An Indian Perspective. Natl Med J India. 2016 Sep-Oct;29(5)257-261.

[Crossref]

19. Balajee KL, Ramachandran N, Subitha L. Awareness and Attitudes toward Organ donation in Rural Puducherry, India. Annals of Medical and Health science research. 2016;6(5)286-90. [Crossref]

20. Odusanya OO, Ladipo CO. Organ donationknowledge, attitudes, and practice in Lagos, Nigeria. Artif Organs. 2006 Aug;30(8)626-9.

[Crossref]

21. Guleria K, Singh AK, Kumar B, Agrawal $P$, Agrawal $S$. Trends of organ donation and awareness in Ernakulam, Kerala. BMC Proc. 2012;6(S4)6561.

[Crossref]

22. Saleem T, Ishaque $S$, Habib $N$, Syedda $S$, Hussain, Jawed A, Khanet AA, et al. Knowledge, attitudes and practices survey on organ donation among a selected adult population of Pakistan. BMC Medical ethics. 2009;10;5. [Crossref]

23. Sander SL, Miller BK. Public knowledge and attitudes regarding organ and tissue donationan analysis of the northwest Ohio community. Patient Education and Counseling. 01 Aug 2005,58(2)154-163.

DOI: $10.1016 /$ j.pec.2004.08.003 [Crossref]
24. Bapat U, Kedlaya PG, Gokulnath. Organ donation, awareness, attitudes and beliefs among post graduate medical students. Saudi J Kidney Dis Transpl. 2010 Jan; 21(1)174-80. [Crossref]

25. Wig N, Aggarwal P, Kailash S, Handa R, Wali JP. Awareness of brain death and organ transplantation among office-goers in New Delhi. Natl Med J India. 1997;10;303-4.

[Crossref]

26. Zhang L, Li Y, Zhou J, Miao $X$, et al. Knowledge and willingness toward living organ donation- a survey of three universities in Changsha, Hunan Pro-vince, China. Transplant Proc. 2007Jun;39(5)1303-9.

[Crossref]

27. El-Shoubaki $H$, Bener A. Public knowledge and attitudes toward organ donation and transplantation- a cross-cultural study. Transplant Proc. 2005 Jun;37(5)1993-7.

DOI: $10.1016 / \mathrm{j}$. transproceed.2005.03.014 [Crossref]

28. Coelho JC, CiliãoC, Parolin MB, et al. [Opinion and knowledge of the population of a Brazilian city about organ donation and transplantation]. Rev Assoc Med Bras. 2007 Sep-Oct;53(5)421-5. [Crossref]

29. Manojan K, Raja RA, Nelson V, Beevi N, Jose R. Knowledge and attitude towards organ donation in rural Kerala. Acad Med J India. 2014;II;25-7. [Crossref]

30. Chung CK, Ng CW, Li JY, et al. Attitudes, knowledge, and actions with regard to organ donation among Hong Kong medical students. Hong Kong Med J. 2008 Aug;14(4)278-85. [Crossref] 